\title{
Selected Medicinal Herbs and Functional Peptides for Protection against Photoaging of the Skin
}

\author{
Yanshan Liang1, Meiyin $\mathrm{Wu}^{2}$, Yafei Chen ${ }^{1^{*}}$ \\ ${ }^{1}$ Infinitus R\&D Center, Infinitus (China) Company Ltd., Guangzhou, China \\ ${ }^{2}$ Guangzhou Hongyun Medical Scientific and Technological Co., Ltd., Guangzhou, China \\ Email: ^Irene.Chen@infinitus-int.com
}

How to cite this paper: Liang, Y.S., Wu, M.Y. and Chen, Y.F. (2019) Selected Medicinal Herbs and Functional Peptides for Protection against Photoaging of the Skin. Journal of Cosmetics, Dermatological Sciences and Applications, 9, 1-18.

https://doi.org/10.4236/jcdsa.2019.91001

Received: December 12, 2018

Accepted: January 11, 2019

Published: January 15, 2019

Copyright $\odot 2019$ by author(s) and Scientific Research Publishing Inc.

This work is licensed under the Creative

Commons Attribution International

License (CC BY 4.0).

http://creativecommons.org/licenses/by/4.0/

\begin{abstract}
Photoaging is an accelerating aging process of the skin due to prolonged exposure to UV from the Sun or other sources. Herbal extracts, natural compounds, and bioactive polypeptides have widely used in cosmetic agents for protection of the skin against photoaging. This mini review briefly summarizes topical use of selected most common medicinal herbs, naturopathic chemicals, and bioactive peptides examined for skin protection.
\end{abstract}

\section{Keywords}

Photoaging, Herbal Extract, Bioactive Peptides, Skincare

\section{Introduction}

Cumulative cutaneous exposure to solar or artificial ultraviolet (UV) radiation results in premature aging changes of the skin, i.e., photoaging, which is directly superimposed on the aging changes of the skin beyond the chronological intrinsic senescence, and accounts for the majority of age-related skin problems [1]. Besides pathophysiological impacts on the skin health, skin aging directly deteriorates the appearance and affects people's behavior and interpersonal interactions. Everyone perhaps is keen to have a youthful-looking skin. Since the chrono-aging process is inevitable, to protect the skin cosmetically from photoaging lesions is critical to slow down the overall aging process. There are numerous cosmetic and dermatological products on the market or on the way being developed. These products may be formulated with biochemicals (such as peptides and growth factors), phytochemicals, traditional herbal extracts, and other ma- 
terials. This mini review discusses benefits and undergoing challenges for combined cosmetic use of functional peptides and extracts from selected traditional Chinese medicine (TCM) herbs for anti-photoaging.

\section{Molecular Pathology of Skin Photoaging}

Photoaging of the skin is also known as dermatoheliosis. The early changes of photoaging in the human skin includes patchy or spotted pigmentation, dryness, wrinkling, laxity (looseness), sagging/droopy, and so on. Photoaging directly results from the loss of structural integrity of the dermal architecture due to lesions in the dermal extracellular matrix (ECM), particularly the destruction of collagens and elastic fibers, which provide strength and resilience to the skin [2]. These pathologic lesions take decades to develop and are different from sunburn and tanning changes, which usually develop in hours to days. As the largest organ of the human body, skin consists of three layers, i.e., the epidermis, the dermis, and the hypodermis or subcutis, from the outmost to the innermost layer [3]. The epidermis is the primary protective structure and is further divided into the acellular stratum corneum and the variable epidermis that is composed of nucleated cells including about $95 \%$ keratinocytes and is devoid of blood capillaries and sensory nerve termini. The dermis and subcutis are a supporting fibrous layer and a subcutaneous layer that is made principally of fat and connective cells/tissues underneath, respectively. In addition to the major structural proteins, collagen and elastin, the dermis contains most active cells including various types of immune cells such as macrophages, lymphocytes, mast cells, dermal dendritic cells, and other functional structures, which may include sweat glands, sebaceous glands, hair follicles, nerve termini, lymphatic vessels and as well as blood capillaries. When the skin is exposed to the UV in sunray or from an artificial source, its structures and associated function can be impaired at different levels through multiple approaches.

As briefly summarized in the schematic in Figure 1, directly exposed to sunlight the skin may capture about 5\% - 10\% UVB and 90\% - 95\% UVA from the solar radiation, while the rest of solar UV including all UVC is filtered by atmosphere (ozone). Once reached to the skin, the UV radiation energy may directly break DNA strands, disrupt structures of nucleotides and proteins/enzymes to cause mutations and changes in metabolism in cells, and overproduction of reactive oxygen species (ROS) [4], which further contributes to the damage of DNA and proteins, lipid peroxidation, depletion of endogenous antioxidants, and other lesions relevant to the oxidative stress [5] [6]. UV (especially UVB) energy directly induces the formation of pyrimidine-pyrimidone and/or thymine-thymine dimers [7] [8]. In addition to the UV, studies suggest a role of infrared (IR) A (wavelength $=760 \mathrm{~nm}-1440 \mathrm{~nm}$ ) in the development of oxidative stress enhancing UV-induced damage through completely different mechanisms in skin cells [9] [10], although there is experimental evidence showing that far-IR suppresses UVB-induced photoaging process [11]. 


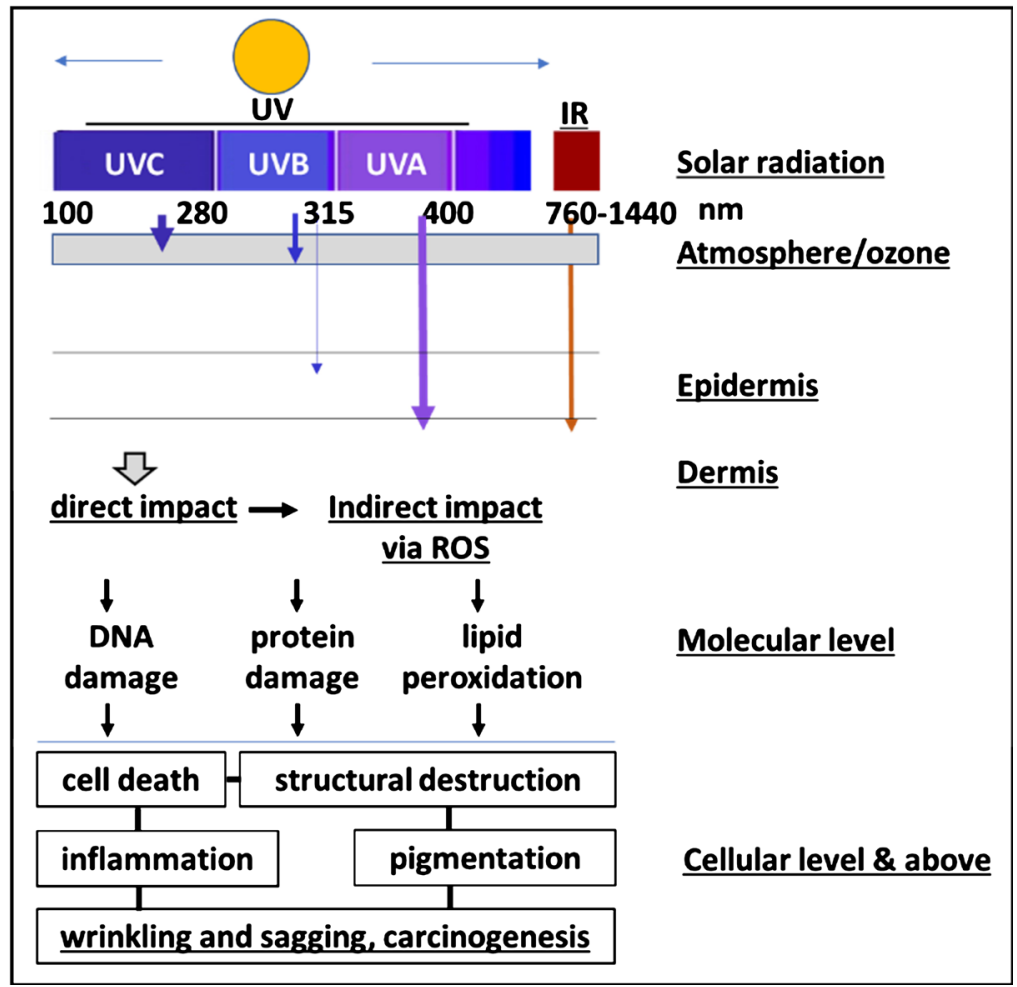

Figure 1. Schematic summary of skin damage induced by solar radiation. Ultraviolet (UV) is a part of the solar radiation with a wavelength from $100 \mathrm{~nm}$ to $400 \mathrm{~nm}$ and makes up an estimated $10 \%$ of the total light output of the Sun. It is further divided into UVA (315 - $400 \mathrm{~nm})$, UVB $(280-315 \mathrm{~nm})$, and UVC (100 - $280 \mathrm{~nm})$. The atmosphere blocks all UVC and about $90 \%$ of UVB. When the rest of UVB and UVA light hits our skin, it can penetrate the epidermis and dermis layers inducing biomolecule damage and subsequent photoaging changes.

Elevation of ROS levels in the skin following photooxidative stress drives production of lipofuscin, a mixed end-product of intracellular lipid peroxidation and oxidized proteins, which is also called as "ceroid" or "age pigment", once it becomes visible in the skin in old people with the naked eye [12]. Protein oxidation leads to abnormal protein degradation due to failure of the ubiquitin-proteasomal as well as the lysosomal-endosomal systems [13] [14]. As a result, oxidized proteins have high propensity form aggregates to build up amyloid deposits inside and/or outside cells [15] [16] [17] [18]. Voluminous evidence suggests that the formation of amyloid deposits be widely implicated in aging as well as many age-related diseases [19] [20], though it is unclear about the precise role that the oxidized protein aggregation plays in the process of skin photoaging. Moreover, oxidative stress promotes the genesis of glycotoxins, advanced glycation end products (AGEs), a highly heterogeneous group of compounds that result from the non-enzymatic glycation of proteins, lipids, and nucleic acids [21]. Accumulation of AGEs in specific tissues has been implicated in multiple diseases and age-related lesions such as diabetes and macular degeneration [21] [22]. Cutaneous buildup of AGEs is known as a feature of skin aging [23]. 
AGEs severely damage dermis through the AGE receptor (RAGE)-mediated impairments in keratinocytes and other components [23].

The immediate consequence of UV-induced lesions in DNA, protein, and lipid molecules is the dysfunction of these biomolecules and activation of related signal transduction pathways leading to further damage at both subcellular/organellular and cellular levels [24] [25]. UV radiation trims telomeres and UV-induced formation of thymine-thymine dimers activates the signal transduction pathways of P53 protein, a tumor suppressor gene product that plays a crucial role in DNA repair, programmed cell death, and tumorigenesis [26] [27], while increased ROS abundance triggers multiple signal transduction pathways including redox factor 1 (Ref-1), hypoxia-inducible factor-1 (HIF-1) in response to oxidative stress [28] [29]. Other pathways involved in the photooxidative stress also include multiple transcription factors and kinases such as the nuclear factor-kappa B (NF- $\kappa$ B)/P65, AP-1, JAK/STAT, Nrf2, the mitogen-activated protein kinase (MAPK), the extracellular signal-regulated kinase (ERK), PI3K, JNK and so on (see reviews) [6] [30].

UV radiation-induced activation of the multiple pathways accounts for subsequent cell loss, inflammation, immunosuppression, and a series of oxidative stress-mediated modifications on cell structures as well as ECM in the skin. Histologically, UV exposures cause apoptosis in both fibroblasts and keratinocytes, abnormal proliferation at or a loss of their proliferating potency to repair lesions [31] [32] [33]; UV-activated inflammatory response consists of an infiltration of various inflammatory cells mainly including neutrophils, monocytes/macrophages [34]; and both residential mast cells and dendritic cells also play an essential role in the pathogenesis of the photoaging process [35] [36] [37]. Changes in the intracellular signal transduction pathways are further followed by remodeling of the ECM due to the reconstruction of collagen (fragmentation) and elastin (elastosis) as a result of alterations in the matrix metalloproteinase (MMP) network [38]. Taken together, all these changes at molecular and cellular levels contribute to the development of photoaging appearance: coarseness, irregular epidermal thickness, sagging, uneven pigmentation, telangiectasia or spider veins, wrinkling, and cutaneous malignancies [39].

\section{Strategies for Anti-Photoaging-The Use of Herbs}

The best way to protect our skin from photoaging is to avoid over-exposure to solar radiation or other UV sources. But in fact, photoaging is very commonly seen in a dermatologic clinic and remains as an unsolved problem for us. Nevertheless, antioxidants are considered as main therapeutic elements for combating both photoaging and natural aging [40]. Due to the presence of abundant antioxidant ingredients in plants, the use of medicinal herbs and/or herbal extracts for skincare has had a long history since ancient times, and it is significantly active in the dermatologic and cosmetic practice [41] [42] [43]. In addition, herbal extracts are natural, relatively stable, and safe to use, if original 
plants have been commonly used in traditional medicines [41]. Many herbal extracts or purified phytochemicals used for skin protection also have strong potency of UV adsorption, anti-inflammation, and/or hydrating, which reduces or blocks UV exposure, attenuates the inflammatory process and apoptotic cell death, and facilitates wound healing [44] [45] [46]. A large number of herbal blend or formulations have been extensively used for anti-skin aging including photoaging in natural medicines such as TCM in personal care [46] [47] [48]. Depending on the differences between herbs, derived crude extracts and/or purified phytochemical(s) may be used alone or combined with other skin protective agents [49] [50]. The leaves, fruits, seeds, barks, stems, and/or roots of these plants contain alkaloids, flavonoids, polyphenols, polysaccharides, proteins, and/or other nutrient molecules (Table 1). For instance, the root of Astragalus (Radix astragali, huangqi) and ginseng (Panax ginseng, renshen) are the two best-known Chinese herbs, which are used traditionally to strengthen the immune system, boost the energy, and promote skin health, other popular herbs such as aloe leaf, tea-tree seed oil, reishi mushroom, safflower and more are widely used in TCM for similar purpose [51].

Most herbal medicines consist of many different ingredients, of which some of these provide benefits and some of other components may be toxic and give risk to our health when used in vivo [77]. Many herbs and derived preparations are photototoxic and/or photogenotoxic to cells [78]. Topical use of these phototoxic phytochemicals may result in allergy, inflammatory reaction, cell death, and/or skin cancer [79] [78]. In this regard, purified photostable phytochemicals

Table 1. Selected TCM herbs and herbal extracts commonly used for anti-photoaging.

\begin{tabular}{|c|c|c|c|}
\hline Component & Main source & Known leading bioactive components & References \\
\hline Extracts & Aloe vera (aloe, luhuí) leaf & Anthraquinones, auxins, gibberellins & $\begin{array}{l}{[52][53][54]} \\
{[55]}\end{array}$ \\
\hline Essential oil & Boswellia sacra (frankincense, ruxiang) & Boswellic acids & [56] \\
\hline Essential oil/extracts & Camellia (tea tree, cha) seed, leaf & Catechins, alkaloids & [57] [58] \\
\hline Extracts & Carthamus tinctorius (safflower, honghua) & Flavonoids, alkaloids & [59] \\
\hline Essential oil & Commipora myrrha (moyao) & Guggulsterone, sesquiterpenes & {$[60][61]$} \\
\hline Extracts & Ganoderma lucidum (reishi, lingzhi) & Polysaccharides, dietary fibers, oligosaccharides & [62] [63] \\
\hline Extracts & Glycine max (soybean, dadou) seed & phenolic acids, flavonoids, isoflavonoids & [64] \\
\hline Essential oil/extracts & Hippophae rhamnoides (sea-buckthorn, shaji) fruit, leaf & Phytosterols, flavonoids, phenolic acids & [65] \\
\hline Extracts & Leonuri cardiacae herba (motherwort, yimucao) & Hyperoside, flavonoids, phenolic acids & [66] \\
\hline Extracts & Lithospermum erythrorhizon (gromwell, zicao) root & Shikonin & [67] [68] [69] \\
\hline Extracts & Panax ginseng (ginseng, renshen) root, leaf & Ginsenosides & [70] [71] [72] \\
\hline Extracts & Panax notogensing (sanchi gingseng, sanqi) & Ginsenoside C-Mx, saponins & {$[73][74]$} \\
\hline Essential oil & Radix Angelica (danggui) & m-Creso, osthole & [75] \\
\hline Extracts & Salvia miltiorrhiza BUNGE (red sage, danshen) root & $\begin{array}{l}\text { Magnesium lithospermate B, } \\
\text { tanshinones,cryptotanshinone }\end{array}$ & [76] \\
\hline
\end{tabular}


are more widely used in cosmetic formulations for skin protection against photoaging [30], as potential phototoxic ingredients in mixtures of herbal extracts have been screened out. Table 2 lists a group of selected phytochemicals which are commonly found in popular TCM herbs and demonstrate potent efficacy as an antioxidant, an anti-inflammatory or other cytoprotective agent as described.

\section{The Use of Peptides for Anti-Photoaging}

Beyond herb-related substances, bioactive peptides have been developed for the purpose of skin protection from natural aging as well as photoaging. Peptides are involved in many physiological processes including cell death, immune response and inflammatory process, skin structural remodeling, and wound healing though modulating related signal transduction pathways and related metabolism [105] [106]. As listed in Table 3, peptides may be grouped as ECM-, growth factor-, neurotransmitter-, enzyme inhibitor-, antioxidant-, cytokine-, and carrier-related peptides. Topical uses of cosmeceutical peptides are expected to stimulate collagen synthesis, inhibit the release of neurotransmitters and inflammatory cytokines in order to attenuate UV radiation-induced lesions and to prevent the development of fine lines and wrinkles as a result of photoaging as well as natural aging [107]. In most cases, in fact, a specific peptide usually has multiple targets and results complex efficacy. For example, topical use of an ECM protein-derived tetrapeptide PKEK boosts formation of ECM and also modulates skin pigmentation resulting in skin whitening effects [108] [109]. As of today, a public database, the TopicalPdb (http://crdd.osdd.net/raghava/topicalpdb/) has currently included 657 entries for the peptides that can be topically delivered [110].

Table 2. Selected herbal compounds/phytochemicals commonly used for anti-photoaging.

\begin{tabular}{llll}
\hline Extract & Main source & Known pharmacological efficacy & References \\
\hline Baicalein & Radix Scutellariae & UV adsorption, antioxidant, anti-inflammatory & {$[80][81][45]$} \\
Boswellic acids & Boswellia sacra (frankincense, ruxiang) gum resin & Anti-inflammatory & {$[82][83]$} \\
Kaempferol & Common fruits such as apples, grapes & Antioxidant, suppress carcinogenesis & {$[84]$} \\
Morin & Members of the Moraceae family & Antioxidant, anti-inflammatory, antibacterial & {$[85][86]$} \\
Myricetin & Berries, fruits, vegetables & Antioxidant, anti-inflammatory & [87] [88] [89] \\
Naringenin & Grapefruit, bergamot, sour orange & Antioxidant, apoptotic inhibition & [90] [91] \\
Nobiletin & Citrus & Antioxidant, anti-inflammatory & [92] \\
Paeoniflorin & Paeonia (moutan) & Anti-inflammatory & [93] [94] \\
Pycnogenol & French maritime pine bark & Antioxidant, anti-wrinkle & [95] [96] \\
Quercetin & Common fruits and food such as apples, grapes & Antioxidant, anti-inflammatory & {$[97][98]$} \\
Rutin & Buckwheat, asparagus & UV adsorption, antioxidant & [99] [100] [45] \\
Salidroside & Rhodiola rosea root & Antioxidant, anti-wrinkle, anti-carcinogenesis & {$[101][102]$} \\
Wogonin & Radix Scutellariae & Antioxidant, anti-inflammatory & {$[103][104]$} \\
\hline
\end{tabular}


Table 3. Selected polypeptides topically used in cosmetics for anti-photoaging.

\begin{tabular}{|c|c|c|}
\hline Type of Peptide & Name of Peptides & References \\
\hline ECM-related peptides & $\begin{array}{l}\text { Carnosine, tripeptide-10 citrulline, collagen tripeptide, acetyl tetrapeptides }(-5,-9,-11) \text {, tetrapeptide } \\
\text { PKEK, GEKG (tetrapeptide-21), hexapeptide, hexapeptide-11, palmitoyl polypeptides } \\
\text { (-pentapeptide-4, -tripeptide- } 1 \text {, -tripeptide-5, -tetra-peptide- } 7 \text {, -hexapeptide-12), oligopeptide- } 1 \text {, } \\
\text { pentamide- } 6\end{array}$ & [107] [111] \\
\hline $\begin{array}{l}\text { Growth factor-related } \\
\text { peptides }\end{array}$ & $\begin{array}{l}\text { sh-oligopeptide-1, epidermal growth factor (EGF), fibroblast growth factor (FGF), insulin-like } \\
\text { growth factor (IGF-1), transforming growth factor (TGF- } \beta \text {, vascular endothelial growth factor } \\
\text { (VEGF), platelet-derived growth factor (PDGF-A), GHK tripeptide, palmitoyl pentapeptide-3 } \\
\text { (pal-KTTKS), KTTKS pentapeptide }\end{array}$ & [112] [113] \\
\hline $\begin{array}{l}\text { Neurotransmitter } \\
\text { inhibiting peptides }\end{array}$ & Acetylhexapeptide-3, pentapeptide- 3 , pentapeptide- 18 , tripeptide- 3 , hexapeptide- 8 (Argireline), & [107] \\
\hline $\begin{array}{l}\text { Enzyme inhibiting } \\
\text { peptides }\end{array}$ & $\begin{array}{l}\text { Pro-collagen C peptide (YYRADDA), black rice oligopeptides, glutathione (GSH), melanocyte } \\
\text { stimulating hormone (MSH), soybean peptide, silk fibroin peptide, AcTP-1, AcTP-2, T10-C, }\end{array}$ & $\begin{array}{ll}{[114]} & {[107]} \\
{[115]}\end{array}$ \\
\hline $\begin{array}{l}\text { Cytokines \& other } \\
\text { peptides }\end{array}$ & Interferon- $\alpha$, heat shock protein-70, peptamide- 6 , keratin & [114] [115] \\
\hline Carrier peptides & Copper tripeptide, manganese tripeptide- 1 & [114] [107] \\
\hline
\end{tabular}

\section{Combined use of herbal extracts/phytochemicals and functional peptides for skin protection against photoaging}

It used to be assumed that, because of the skin barrier, peptides with the molecular weight over 500 Daltons would not be able to pass the barrier [116]. But recent experimental evidence has shown that bigger protein molecules can still pass through the skin barrier, especially in the case of the skin which is stressed and aged and/or injured [117]. Importantly, the skin penetration potency of synthetic peptides can be further modulated by various factors, which directly modify skin permeability, increase the ligand-receptor binding and stability and solubility [109] [118]. Combined use of herbal extracts or phytochemical with functional peptides has been shown to boost the efficacy of bioactive peptides, as herbal components such as polyphenols and flavonoids bind to peptides promoting their penetration to the skin, increasing the lifetime of peptides, and thereby significantly enhance the protection efficacy against UV-induced damage as well as natural aging [119]. Studies demonstrate that topical application of herbal extracts or phytochemicals such as apigenin or hesperidin dramatically enhances epidermal permeability and modifies the barrier function of the skin in animal studies [120] [121] [122]. We also observed that combined topical use of polypeptide mixtures and herbal extracts markedly enhanced proliferation of epidermal cells in SKH-1 hairless mice following UV-induced photoaging (Figure 2).

In spite of the advantages of synergistic interaction between herbal ingredients and bioactive peptides, there are still open questions about combined topical use of naturopathic components and functional peptides. The important questions would be how two different groups of components interact with each other to enhance the transdermal process, to affect their pharmacological efficacy as well as other pharmacokinetic issues. Mixing one or multiple types of herbal compounds 

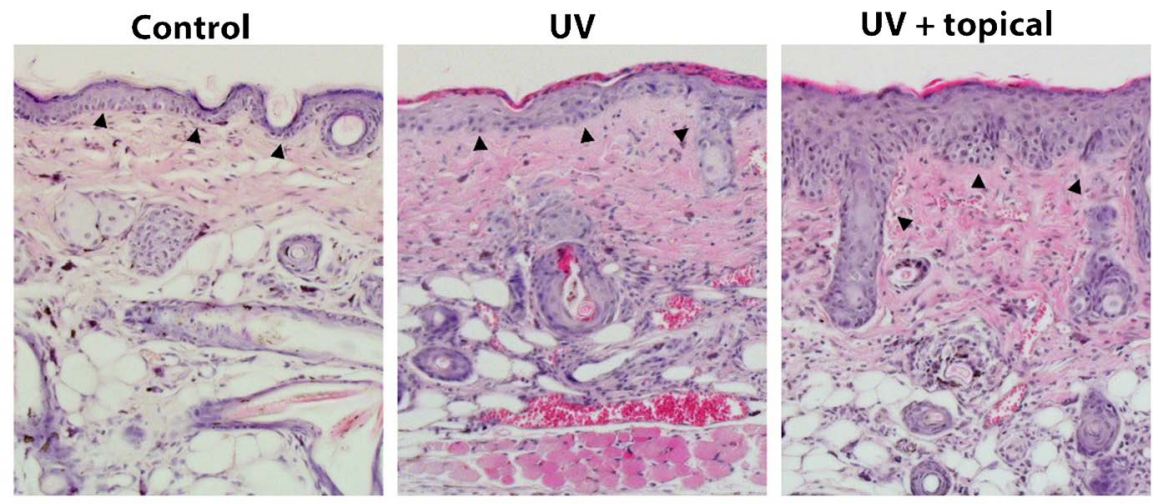

Figure 2. Combined topical use of herbal extracts and bioactive peptides shows evident protection against UV-induced photoaging in SHK-1 hairless mice (unpublished observations). SHK-1 mice were exposed to UV light ( $\times 6$ days) and given topically (daily) blank lotion (UV) or lotion containing polypeptides (a mixture of oligopeptide-1, palmitoyl pentapeptide, and carnosine) and herbal extracts of $S$. miltiorrhiza, $P$. ginseng, $P$. notoginseng, and G. lucidum (UV + topical). Following conventional hematoxylin-eosin (H \& E) staining of the back skin sections prepared from the mice, light microscopic images $(20 \times 10)$ demonstrate photoaging changes in UV-exposed mice given blank lotion (UV) compared to the Control (arrowheads), while those given herbal and peptide mixtures (UV + topical) manifest enhanced epidermis proliferation.

with peptides is not simple addition. In addition to directly binding with peptides/proteins through either a specific or a non-specific manner resulting in a change in their bioactivities [123] [124], a variety of herbal compounds such as polyphenols and flavonoids act on membrane lipids and change cell membrane properties affecting epidermal permeability [125]. In fact, in some cases these types of interactions lead to an antagonistic result [126]. Therefore, this is an important issue for cosmetics to consider. Mutual interactions between herbal compounds and polypeptides following combination may occur and change their original pharmacological properties. Answers to these questions will lead to the development of new preventive and therapeutic drugs and/or formulations for both cosmetic and pharmaceutical industries.

\section{Conflicts of Interest}

The authors declare no conflicts of interest regarding the publication of this paper.

\section{References}

[1] D'Orazio, J., Jarrett, S., Amaro-Ortiz, A. and Scott, T. (2013) UV Radiation and the Skin. International Journal of Molecular Sciences, 14, 12222-12248. https://doi.org/10.3390/ijms140612222

[2] Battie, C., Jitsukawa, S., Bernerd, F., Del Bino, S., Marionnet, C. and Verschoore, M. (2014) New Insights in Photoaging, UVA Induced Damage and Skin Types. Experimental Dermatology, 23, 7-12. https://doi.org/10.1111/exd.12388

[3] Ng, K.W. and Lau, W.M. (2015) Skin Deep: The Basics of Human Skin Structure and Drug Penetration. 
[4] Heck, D.E., Vetrano, A.M., Mariano, T.M. and Laskin, J.D. (2003) UVB Light Stimulates Production of Reactive Oxygen Species: Unexpected Role for Catalase. The Journal of Biological Chemistry, 278, 22432-22436. https://doi.org/10.1074/jbc.C300048200

[5] Burke, K.E. (2010) Photoaging: The Role of Oxidative Stress. Giornale Italiano di Dermatologia e Venereologia, 145, 445-459.

[6] Rinnerthaler, M., Bischof, J., Streubel, M.K., Trost, A. and Richter, K. (2015) Oxidative Stress in Aging Human Skin. Biomolecules, 5, 545-589. https://doi.org/10.3390/biom5020545

[7] Lippke, J.A., Gordon, L.K., Brash, D.E. and Haseltine, W.A. (1981) Distribution of UV Light-Induced Damage in a Defined Sequence of Human DNA: Detection of Alkaline-Sensitive Lesions at Pyrimidine Nucleoside-Cytidine Sequences. Proceedings of the National Academy of Sciences of the United States of America, 78, 3388-3392. https://doi.org/10.1073/pnas.78.6.3388

[8] Nishigori, C. (2006) Cellular Aspects of Photocarcinogenesis. Photochemical \& Photobiological Sciences, 5, 208-214. https://doi.org/10.1039/B507471A

[9] Schroeder, P., Calles, C. and Krutmann, J. (2009) Prevention of Infrared-A Radiation Mediated Detrimental Effects in Human Skin. Skin Therapy Letter, 14, 4-5.

[10] Schroeder, P., Haendeler, J. and Krutmann, J. (2008) The Role of Near Infrared Radiation in Photoaging of the Skin. Experimental Gerontology, 43, 629-632. https://doi.org/10.1016/j.exger.2008.04.010

[11] Chiu, H.W., Chen, C.H., Chen, Y.J. and Hsu, Y.H. (2017) Far-Infrared Suppresses Skin Photoaging in Ultraviolet B-Exposed Fibroblasts and Hairless Mice. PLoS One, 12, e0174042. https://doi.org/10.1371/journal.pone.0174042

[12] Hohn, A. and Grune, T. (2013) Lipofuscin: Formation, Effects and Role of Macroautophagy. Redox Biology, 1, 140-144. https://doi.org/10.1016/j.redox.2013.01.006

[13] Jung, T. and Grune, T. (2013) The Proteasome and the Degradation of Oxidized Proteins: Part I-Structure of Proteasomes. Redox Biology, 1, 178-182. https://doi.org/10.1016/j.redox.2013.01.004

[14] Jung, T. and Grune, T. (2008) The Proteasome and Its Role in the Degradation of Oxidized Proteins. IUBMB Life, 60, 743-752. https://doi.org/10.1002/iub.114

[15] Widmer, R., Ziaja, I. and Grune, T. (2006) Protein Oxidation and Degradation during Aging: Role in Skin Aging and Neurodegeneration. Free Radical Research, 40, 1259-1268. https://doi.org/10.1080/10715760600911154

[16] Sander, C.S., Chang, H., Salzmann, S., Muller, C.S., Ekanayake-Mudiyanselage, S., Elsner, P. and Thiele, J.J. (2002) Photoaging Is Associated with Protein Oxidation in Human Skin in Vivo. Journal of Investigative Dermatology, 118, 618-625. https://doi.org/10.1046/j.1523-1747.2002.01708.x

[17] Clos, A.L., Lasagna-Reeves, C.A., Wagner, R., Kelly, B., Jackson, G.R. and Kayed, R. (2010) Therapeutic Removal of Amyloid Deposits in Cutaneous Amyloidosis by Localised Intra-Lesional Injections of Anti-Amyloid Antibodies. Experimental Dermatology, 19, 904-911. https://doi.org/10.1111/j.1600-0625.2010.01121.x

[18] Weids, A.J., Ibstedt, S., Tamás, M.J. and Grant, C.M. (2016) Distinct Stress Conditions Result in Aggregation of Proteins with Similar Properties. Scientific Reports, 6, Article No. 24554. https://doi.org/10.1038/srep24554

[19] Squier, T.C. (2001) Oxidative Stress and Protein Aggregation during Biological Aging. Experimental Gerontology, 36, 1539-1550. 
https://doi.org/10.1016/S0531-5565(01)00139-5

[20] Stroo, E., Koopman, M., Nollen, E.A. and Mata-Cabana, A. (2017) Cellular Regulation of Amyloid Formation in Aging and Disease. Frontiers in Neuroscience, 11, 64. https://doi.org/10.3389/fnins.2017.00064

[21] Turner, D.P. (2015) Advanced Glycation End-Products: A Biological Consequence of Lifestyle Contributing to Cancer Disparity. Cancer Research, 75, 1925-1929. https://doi.org/10.1158/0008-5472.CAN-15-0169

[22] Yamagishi, S., Maeda, S., Matsui, T., Ueda, S., Fukami, K. and Okuda, S. (2012) Role of Advanced Glycation End Products (Ages) and Oxidative Stress in Vascular Complications in Diabetes. Biochimica et Biophysica Acta (BBA)-General Subjects, 1820, 663-671. https://doi.org/10.1016/j.bbagen.2011.03.014

[23] Gkogkolou, P. and Bohm, M. (2012) Advanced Glycation End Products: Key Players in Skin Aging? Dermato-Endocrinology, 4, 259-270.

https://doi.org/10.4161/derm.22028

[24] Rittie, L. and Fisher, G.J. (2015) Natural and Sun-Induced Aging of Human Skin. Cold Spring Harbor Perspectives in Medicine, 5, a015370. https://doi.org/10.1101/cshperspect.a015370

[25] Mohania, D., Chandel, S., Kumar, P., Verma, V., Digvijay, K., Tripathi, D., Choudhury, K., Mitten, S.K. and Shah, D. (2017) Ultraviolet Radiations: Skin Defense-Damage Mechanism. In: Ahmad, S., Ed., Ultraviolet Light in Human Health, Diseases and Environment. Advances in Experimental Medicine and Biology, Vol. 996, Springer, Cham, 71-87. https://doi.org/10.1007/978-3-319-56017-5_7

[26] Maclaine, N.J. and Hupp, T.R. (2009) The Regulation of p53 by Phosphorylation: A Model for How Distinct Signals Integrate into the p53 Pathway. Aging (Albany NY), 1, 490-502. https://doi.org/10.18632/aging.100047

[27] Molho-Pessach, V. and Lotem, M. (2007) Ultraviolet Radiation and Cutaneous Carcinogenesis. Current Problems in Dermatology, 35, 14-27. https://doi.org/10.1159/000106407

[28] Rezvani, H.R., Dedieu, S., North, S., Belloc, F., Rossignol, R., Letellier, T., de Verneuil, H., Taieb, A. and Mazurier, F. (2007) Hypoxia-Inducible Factor-1Alpha, a Key Factor in the Keratinocyte Response to UVB Exposure. The Journal of Biological Chemistry, 282, 16413-16422. https://doi.org/10.1074/jbc.M611397200

[29] Ray, P.D., Huang, B.W. and Tsuji, Y. (2012) Reactive Oxygen Species (ROS) Homeostasis and Redox Regulation in Cellular Signaling. Cellular Signalling, 24, 981-990. https://doi.org/10.1016/j.cellsig.2012.01.008

[30] Bosch, R., Philips, N., Suarez-Perez, J.A., Juarranz, A., Devmurari, A., Chalensouk-Khaosaat, J. and Gonzalez, S. (2015) Mechanisms of Photoaging and Cutaneous Photocarcinogenesis, and Photoprotective Strategies with Phytochemicals. Antioxidants (Basel), 4, 248-268.

[31] Bernerd, F. and Asselineau, D. (1998) UVA Exposure of Human Skin Reconstructed in Vitro Induces Apoptosis of Dermal Fibroblasts: Subsequent Connective Tissue Repair and Implications in Photoaging. Cell Death \& Differentiation, 5, 792-802. https://doi.org/10.1038/sj.cdd.4400413

[32] Lee, C.H., Wu, S.B., Hong, C.H., Yu, H.S. and Wei, Y.H. (2013) Molecular Mechanisms of UV-Induced Apoptosis and Its Effects on Skin Residential Cells: The Implication in UV-Based Phototherapy. International Journal of Molecular Sciences, 14, 6414-6435. https://doi.org/10.3390/ijms14036414

[33] Li, L., Chen, X. and Gu, H. (2016) The Signaling Involved in Autophagy Machinery in Keratinocytes and Therapeutic Approaches for Skin Diseases. Oncotarget, 7, 
50682-50697. https://doi.org/10.18632/oncotarget.9330

[34] Bennett, M.F., Robinson, M.K., Baron, E.D. and Cooper, K.D. (2008) Skin Immune Systems and Inflammation: Protector of the Skin or Promoter of Aging? Journal of Investigative Dermatology Symposium Proceedings, 13, 15-19. https://doi.org/10.1038/jidsymp.2008.3

[35] Fukunaga, A., Khaskhely, N.M., Sreevidya, C.S., Byrne, S.N. and Ullrich, S.E. (2008) Dermal Dendritic Cells, and Not Langerhans Cells, Play an Essential Role in Inducing an Immune Response. The Journal of Immunology, 180, 3057-3064. https://doi.org/10.4049/jimmunol.180.5.3057

[36] Siiskonen, H., Smorodchenko, A., Krause, K. and Maurer, M. (2018) Ultraviolet Radiation and Skin Mast Cells: Effects, Mechanisms and Relevance for Skin Diseases. Experimental Dermatology, 27, 3-8. https://doi.org/10.1111/exd.13402

[37] Hart, P.H., Grimbaldeston, M.A., Swift, G.J., Jaksic, A., Noonan, F.P. and Finlay-Jones, J.J. (1998) Dermal Mast Cells Determine Susceptibility to Ultraviolet B-Induced Systemic Suppression of Contact Hypersensitivity Responses in Mice. The Journal of Experimental Medicine, 187, 2045-2053. https://doi.org/10.1084/jem.187.12.2045

[38] Watson, R.E., Gibbs, N.K., Griffiths, C.E. and Sherratt, M.J. (2014) Damage to Skin Extracellular Matrix Induced by UV Exposure. Antioxidants \& Redox Signaling, 21, 1063-1077. https://doi.org/10.1089/ars.2013.5653

[39] Helfrich, Y.R., Sachs, D.L. and Voorhees, J.J. (2008) Overview of Skin Aging and Photoaging. Dermatology Nursing, 20, 177-183; quiz 184.

[40] Pandel, R., Poljsak, B., Godic, A. and Dahmane, R. (2013) Skin Photoaging and the Role of Antioxidants in Its Prevention. ISRN Dermatology, 2013, Article ID: 930164. https://doi.org/10.1155/2013/930164

[41] Kumar, D., Rajora, G., Parkash, O., Himanshu, M., Antil, V. and Kumar, V. (2016) Herbal Cosmetics: An Overview. International Journal of Advanced Scientific Research, 1, 36-41.

[42] Chermahini, S.H., Majid, F.A.A. and Sarmidi, M.R. (2011) Cosmeceutical Value of Herbal Extracts as Natural Ingredients and Novel Technologies in Anti-Aging. Journal of Medicinal Plants Research, 5, 3074-3077.

[43] Saha, R. (2012) Cosmeceuticals and Herbal Drugs: Practical Uses. International Journal of Pharmaceutical Sciences and Research, 2, 59-65.

[44] Korac, R.R. and Khambholja, K.M. (2011) Potential of Herbs in Skin Protection from Ultraviolet Radiation. Pharmacognosy Reviews, 5, 164-173.

[45] Kostyuk, V., Potapovich, A., Albuhaydar, A.R., Mayer, W., De Luca, C. and Korkina, L. (2018) Natural Substances for Prevention of Skin Photoaging: Screening Systems in the Development of Sunscreen and Rejuvenation Cosmetics. Rejuvenation Research, 21, 91-101. https://doi.org/10.1089/rej.2017.1931

[46] Kanlayavattanakul, M. and Lourith, N. (2015) An Update on Cutaneous Aging Treatment Using Herbs. Journal of Cosmetic and Laser Therapy, 17, 343-352. https://doi.org/10.3109/14764172.2015.1039036

[47] Kanlayavattanakul, M. and Lourith, N. (2018) Skin Hyperpigmentation Treatment Using Herbs: A Review of Clinical Evidences. Journal of Cosmetic and Laser Therapy, 20, 123-131. https://doi.org/10.1080/14764172.2017.1368666

[48] Chanchal, D. and Swarnlata, S. (2009) Herbal Photoprotective Formulations and Their Evaluation. The Open Natural Products Journal, 2, 71-76. https://doi.org/10.2174/1874848100902010071 
[49] Sahu, R.K., Roy, A., Matlam, M., Kumar Deshmukh, V., Dwivedi, J. and Kumar Jha, A. (2013) Review on Skin Aging and Compilation of Scientific Validated Medicinal Plants, Prominence to Flourish a Better Research Reconnoiters in Herbal Cosmetic. Research Journal of Medicinal Plants, 7, 1-22. https://doi.org/10.3923/rjmp.2013.1.22

[50] Cavinato, M., Waltenberger, B., Baraldo, G., Grade, C.V.C., Stuppner, H. and Jansen-Durr, P. (2017) Plant Extracts and Natural Compounds Used against UVBInduced Photoaging. Biogerontology, 18, 499-516.

https://doi.org/10.1007/s10522-017-9715-7

[51] Lee, K.H., Morris-Natschke, S., Qian, K., Dong, Y., Yang, X., Zhou, T., Belding, E., Wu, S.F., Wada, K. and Akiyama, T. (2012) Recent Progress of Research on Herbal Products Used in Traditional Chinese Medicine: The Herbs Belonging to the Divine Husbandman's Herbal Foundation Canon (Shen Nong Ben Cao Jing). Journal of Traditional and Complementary Medicine, 2, 6-26. https://doi.org/10.1016/S2225-4110(16)30066-9

[52] Li, Y.H., Wu, Y., Wei, H.C., Xu, Y.Y., Jia, L.L., Chen, J., Yang, X.S., Dong, G.H., Gao, X.H. and Chen, H.D. (2009) Protective Effects of Green Tea Extracts on Photoaging and Photommunosuppression. Skin Research and Technology, 15, 338-345. https://doi.org/10.1111/j.1600-0846.2009.00370.x

[53] Lailiyah, I., Prasetyawan, S. and Aulani, A. (2017) Effect of Topical Application of Gel Aloe vera Extract on the UVB-Induced Skin Photoaging in Hairless Rats. The Journal of Pure and Applied Chemistry Research, 6, 112-116. https://doi.org/10.21776/ub.jpacr.2017.006.02.321

[54] Hong, S.W., Chun, J., Park, S., Lee, H.J., Im, J.P. and Kim, J.S. (2018) Aloe vera Is Effective and Safe in Short-Term Treatment of Irritable Bowel Syndrome: A Systematic Review and Meta-Analysis. Journal of Neurogastroenterology and Motility, 24, 528-535. https://doi.org/10.5056/jnm18077

[55] Surjushe, A., Vasani, R. and Saple, D.G. (2008) Aloe vera: A Short Review. Indian Journal of Dermatology, 53, 163-166. https://doi.org/10.4103/0019-5154.44785

[56] DeCarlo, A., Johnson, S., Poudel, A., Satyal, P., Bangerter, L. and Setzer, W.N. (2018) Chemical Variation in Essential Oils from the Oleo-Gum Resin of Boswellia carteri: A Preliminary Investigation. Chemistry \& Biodiversity, 15, e1800047. https://doi.org/10.1002/cbdv.201800047

[57] Banerjee, S. and Chatterjee, J. (2015) Efficient Extraction Strategies of Tea (Camellia sinensis) Biomolecules. Journal of Food Science and Technology, 52, 3158-3168.

[58] Mizutani, T. and Masaki, H. (2014) Anti-Photoaging Capability of Antioxidant Extract from Camellia Japonica Leaf. Experimental Dermatology, 23, 23-26. https://doi.org/10.1111/exd.12395

[59] Delshad, E., Yousefi, M., Sasannezhad, P., Rakhshandeh, H. and Ayati, Z. (2018) Medical Uses of Carthamus tinctorius L. (Safflower): A Comprehensive Review from Traditional Medicine to Modern Medicine. Electronic Physician, 10, 6672-6681. https://doi.org/10.19082/6672

[60] Auffray, B. (2007) Protection against Singlet Oxygen, the Main Actor of Sebum Squalene Peroxidation during Sun Exposure, Using Commiphora myrrha Essential Oil. International Journal of Cosmetic Science, 29, 23-29. https://doi.org/10.1111/j.1467-2494.2007.00360.x

[61] Ge, C.Y. and Zhang, J.L. (2018) Bioactive Sesquiterpenoids and Steroids from the Resinous Exudates of Commiphora myrrha. Natural Product Research, 1-7. https://doi.org/10.1080/14786419.2018.1448811 
[62] Zeng, Q., Zhou, F., Lei, L., Chen, J., Lu, J., Zhou, J., Cao, K., Gao, L., Xia, F., Ding, S., Huang, L., Xiang, H., Wang, J., Xiao, Y., Xiao, R. and Huang, J. (2017) Ganoderma lucidum Polysaccharides Protect Fibroblasts against UVB-Induced Photoaging. Molecular Medicine Reports, 15, 111-116. https://doi.org/10.3892/mmr.2016.6026

[63] Batra, P., Sharma, A.K. and Khajuria, R. (2013) Probing Lingzhi or Reishi Medicinal Mushroom Ganoderma lucidum (Higher Basidiomycetes): A Bitter Mushroom with Amazing Health Benefits. International Journal of Medicinal Mushrooms, 15, 127-143. https://doi.org/10.1615/IntJMedMushr.v15.i2.20

[64] Waqas, M.K., Akhtar, N., Mustafa, R., Jamshaid, M., Khan, H.M. and Murtaza, G. (2015) Dermatological and Cosmeceutical Benefits of Glycine Max (Soybean) and Its Active Components. Acta Poloniae Pharmaceutica, 72, 3-11.

[65] Li, Y. and Hu, C. (2015) Hippophae rhamnoides L. 沙棘 (Shaji, Common Sea-Buckthorn). In: Liu, Y., Wang, Z. and Zhang, J., Eds., Dietary Chinese Herbs. Chemistry, Pharmacology and Clinical Evidence, Springer, Vienna, 403-415. https://doi.org/10.1007/978-3-211-99448-1_46

[66] Wojtyniak, K., Szymanski, M. and Matlawska, I. (2013) Leonurus cardiaca L. (Motherwort): A Review of Its Phytochemistry and Pharmacology. Phytotherapy Research, 27, 1115-1120. https://doi.org/10.1002/ptr.4850

[67] Glynn, K.M., Anderson, P., Fast, D.J., Koedam, J., Rebhun, J.F. and Velliquette, R.A. (2018) Gromwell (Lithospermum erythrorhizon) Root Extract Protects against Glycation and Related Inflammatory and Oxidative Stress While Offering UV Absorption Capability. Experimental Dermatology, 27, 1043-1047. https://doi.org/10.1111/exd.13706

[68] Chang, M.J., Huang, H.C., Chang, H.C. and Chang, T.M. (2008) Cosmetic Formulations Containing Lithospermum erythrorhizon Root Extract Show Moisturizing Effects on Human Skin. Archives of Dermatological Research, 300, 317-323. https://doi.org/10.1007/s00403-008-0867-9

[69] Ishida, T. and Sakaguchi, I. (2007) Protection of Human Keratinocytes from UVB-Induced Inflammation Using Root Extract of Lithospermum erythrorhizon. Biological and Pharmaceutical Bulletin, 30, 928-934.

[70] Kim, M.-R., Han, J., Chang, U.-J. and Suh, H.J. (2013) Protective Effect of Ginseng Leaf Extract against UVB-Induced Photoaging in Hairless Mouse. The FASEB Journal, 27, lb307-lb307.

[71] Hwang, E., Park, S.Y., Yin, C.S., Kim, H.T., Kim, Y.M. and Yi, T.H. (2017) Antiaging Effects of the Mixture of Panax ginseng and Crataegus pinnatifida in Human Dermal Fibroblasts and Healthy Human Skin. Journal of Ginseng Research, 41, 69-77. https://doi.org/10.1016/j.jgr.2016.01.001

[72] Lu, J.M., Yao, Q. and Chen, C. (2009) Ginseng Compounds: An Update on Their Molecular Mechanisms and Medical Applications. Current Vascular Pharmacology, 7, 293-302. https://doi.org/10.2174/157016109788340767

[73] Liu, X.Y., Hwang, E., Park, B., Ngo, H.T.T., Xiao, Y.K. and Yi, T.H. (2018) Ginsenoside C-Mx Isolated from Notoginseng Stem-Leaf Ginsenosides Attenuates Ultraviolet B-Mediated Photoaging in Human Dermal Fibroblasts. Photochemistry and Photobiology, 94, 1040-1048. https://doi.org/10.1111/php.12940

[74] Peng, M., Yi, Y.X., Zhang, T., Ding, Y. and Le, J. (2018) Stereoisomers of Saponins in Panax notoginseng (Sanqi): A Review. Frontiers in Pharmacology, 9, 188. https://doi.org/10.3389/fphar.2018.00188

[75] Chen, D., Du, Z., Lin, Z., Su, P., Huang, H., Ou, Z., Pan, W., Huang, S., Zhang, K., 
Zheng, X., Lin, L. and Zhang, L. (2018) The Chemical Compositions of Angelica pubescens Oil and Its Prevention of UV-B Radiation-Induced Cutaneous Photoaging. Chemistry \& Biodiversity, 15, e1800235. https://doi.org/10.1002/cbdv.201800235

[76] Li, Y., Shi, S., Gao, J., Han, S., Wu, X., Jia, Y., Su, L., Shi, J. and Hu, D. (2016) Cryptotanshinone Downregulates the Profibrotic Activities of Hypertrophic Scar Fibroblasts and Accelerates Wound Healing: A Potential Therapy for the Reduction of Skin Scarring. Biomedicine \& Pharmacotherapy, 80, 80-86. https://doi.org/10.1016/j.biopha.2016.03.006

[77] Zhang, X.-L., Chen, M., Zhu, L.-L. and Zhou, Q. (2017) Therapeutic Risk and Benefits of Concomitantly Using Herbal Medicines and Conventional Medicines: From the Perspectives of Evidence Based on Randomized Controlled Trials and Clinical Risk Management. Evidence-Based Complementary and Alternative Medicine, 2017, Article ID: 9296404. https://doi.org/10.1155/2017/9296404

[78] Fu, P.P., Xia, Q., Zhao, Y., Wang, S., Yu, H. and Chiang, H.M. (2013) Phototoxicity of Herbal Plants and Herbal Products. Journal of Environmental Science and Health. Part C, Environmental Carcinogenesis \& Ecotoxicology Reviews, 31, 213-255. https://doi.org/10.1080/10590501.2013.824206

[79] Gaspar, L.R., Tharmann, J., Maia Campos, P.M. and Liebsch, M. (2013) Skin Phototoxicity of Cosmetic Formulations Containing Photounstable and Photostable UV-Filters and Vitamin A Palmitate. Toxicology in Vitro, 27, 418-425. https://doi.org/10.1016/j.tiv.2012.08.006

[80] Oh, M.C., Piao, M.J., Fernando, P.M., Han, X., Madduma Hewage, S.R., Park, J.E., Ko, M.S., Jung, U., Kim, I.G. and Hyun, J.W. (2016) Baicalein Protects Human Skin Cells against Ultraviolet B-Induced Oxidative Stress. Biomolecules \& Therapeutics, 24, 616-622. https://doi.org/10.4062/biomolther.2016.022

[81] Min, W., Liu, X., Qian, Q., Lin, B., Wu, D., Wang, M., Ahmad, I., Yusuf, N. and Luo, D. (2014) Effects of Baicalin against UVA-Induced Photoaging in Skin Fibroblasts. The American Journal of Chinese Medicine, 42, 709-727. https://doi.org/10.1142/S0192415X14500463

[82] Pedretti, A., Capezzera, R., Zane, C., Facchinetti, E. and Calzavara-Pinton, P. (2010) Effects of Topical Boswellic Acid on Photo and Age-Damaged Skin: Clinical, Biophysical, and Echographic Evaluations in a Double-Blind, Randomized, Split-Face Study. Planta Medica, 76, 555-560. https://doi.org/10.1055/s-0029-1240581

[83] Calzavara-Pinton, P., Zane, C., Facchinetti, E., Capezzera, R. and Pedretti, A. (2010) Topical Boswellic Acids for Treatment of Photoaged Skin. Dermatologic Therapy, 23, S28-S32. https://doi.org/10.1111/j.1529-8019.2009.01284.x

[84] Yao, K., Chen, H., Liu, K., Langfald, A., Yang, G., Zhang, Y., Yu, D.H., Kim, M.O., Lee, M.H., Li, H., Bae, K.B., Kim, H.G., Ma, W.Y., Bode, A.M., Dong, Z. and Dong, Z. (2014) Kaempferol Targets RSK2 and MSK1 to Suppress UV Radiation-Induced Skin Cancer. Cancer Prevention Research (Phila), 7, 958-967. https://doi.org/10.1158/1940-6207.CAPR-14-0126

[85] Shetty, P.K., Venuvanka, V., Jagani, H.V., Chethan, G.H., Ligade, V.S., Musmade, P.B., Nayak, U.Y., Reddy, M.S., Kalthur, G., Udupa, N., Rao, C.M. and Mutalik, S. (2015) Development and Evaluation of Sunscreen Creams Containing MorinEncapsulated Nanoparticles for Enhanced UV Radiation Protection and Antioxidant Activity. International Journal of Nanomedicine, 10, 6477-6491.

[86] Caselli, A., Cirri, P., Santi, A. and Paoli, P. (2016) Morin: A Promising Natural Drug. Current Medicinal Chemistry, 23, 774-791. 
https://doi.org/10.2174/0929867323666160106150821

[87] Kang, N.J., Jung, S.K., Lee, K.W. and Lee, H.J. (2011) Myricetin Is a Potent Chemopreventive Phytochemical in Skin Carcinogenesis. Annals of the New York Academy of Sciences, 1229, 124-132. https://doi.org/10.1111/j.1749-6632.2011.06122.x

[88] Jung, S.K., Lee, K.W., Kim, H.Y., Oh, M.H., Byun, S., Lim, S.H., Heo, Y.S., Kang, N.J., Bode, A.M., Dong, Z. and Lee, H.J. (2010) Myricetin Suppresses UVB-Induced Wrinkle Formation and MMP-9 Expression by Inhibiting Raf. Biochemical Pharmacology, 79, 1455-1461. https://doi.org/10.1016/j.bcp.2010.01.004

[89] Huang, J.H., Huang, C.C., Fang, J.Y., Yang, C., Chan, C.M., Wu, N.L., Kang, S.W. and Hung, C.F. (2010) Protective Effects of Myricetin against Ultraviolet-B-Induced Damage in Human Keratinocytes. Toxicology in Vitro, 24, 21-28.

https://doi.org/10.1016/j.tiv.2009.09.015

[90] El-Mahdy, M.A., Zhu, Q., Wang, Q.E., Wani, G., Patnaik, S., Zhao, Q., Arafa, E.-S., Barakat, B., Mir, S.N. and Wani, A.A. (2008) Naringenin Protects HaCaT Human Keratinocytes against UVB-Induced Apoptosis and Enhances the Removal of Cyclobutane Pyrimidine Dimers from the Genome. Photochemistry and Photobiology, 84, 307-316. https://doi.org/10.1111/j.1751-1097.2007.00255.x

[91] Jung, S.K., Ha, S.J., Jung, C.H., Kim, Y.T., Lee, H.K., Kim, M.O., Lee, M.H., Mottamal, M., Bode, A.M., Lee, K.W. and Dong, Z. (2016) Naringenin Targets ERK2 and Suppresses UVB-Induced Photoaging. Journal of Cellular and Molecular Medicine, 20, 909-919. https://doi.org/10.1111/jcmm.12780

[92] Tanaka, S., Sato, T., Akimoto, N., Yano, M. and Ito, A. (2004) Prevention of UVB-Induced Photoinflammation and Photoaging by a Polymethoxy Flavonoid, Nobiletin, in Human Keratinocytes in Vivo and in Vitro. Biochemical Pharmacolo$g y$, 68, 433-439. https://doi.org/10.1016/j.bcp.2004.04.006

[93] Lee, S., Lim, J.M., Jin, M.H., Park, H.K., Lee, E.J., Kang, S., Kim, Y.S. and Cho, W.G. (2006) Partially Purified Paeoniflorin Exerts Protective Effects on UV-Induced DNA Damage and Reduces Facial Wrinkles in Human Skin. Journal of Cosmetic Science, 57, 57-64.

[94] Kong, L., Wang, S., Wu, X., Zuo, F., Qin, H. and Wu, J. (2016) Paeoniflorin Attenuates Ultraviolet B-Induced Apoptosis in Human Keratinocytes by Inhibiting the ROS-p38-p53 Pathway. Molecular Medicine Reports, 13, 3553-3558. https://doi.org/10.3892/mmr.2016.4953

[95] Marini, A., Grether-Beck, S., Jaenicke, T., Weber, M., Burki, C., Formann, P., Brenden, H., Schonlau, F. and Krutmann, J. (2012) Pycnogenol ${ }^{\circledR}$ Effects on Skin Elasticity and Hydration Coincide with Increased Gene Expressions of Collagen Type I and Hyaluronic Acid Synthase in Women. Skin Pharmacology and Physiology, 25, 86-92. https://doi.org/10.1159/000335261

[96] Cho, H.S., Lee, M.H., Lee, J.W., No, K.O., Park, S.K., Lee, H.S., Kang, S., Cho, W.G., Park, H.J., Oh, K.W. and Hong, J.T. (2007) Anti-Wrinkling Effects of the Mixture of Vitamin C, Vitamin E, Pycnogenol and Evening Primrose Oil, and Molecular Mechanisms on Hairless Mouse Skin Caused by Chronic Ultraviolet B Irradiation. Photodermatology, Photoimmunology \& Photomedicine, 23, 155-162. https://doi.org/10.1111/j.1600-0781.2007.00298.x

[97] Nan, W., Ding, L., Chen, H., Khan, F.U., Yu, L., Sui, X. and Shi, X. (2018) Topical Use of Quercetin-Loaded Chitosan Nanoparticles against Ultraviolet B Radiation. Frontiers in Pharmacology, 9, 826. https://doi.org/10.3389/fphar.2018.00826

[98] Maramaldi, G., Togni, S., Pagin, I., Giacomelli, L., Cattaneo, R., Eggenhoffner, R. and Burastero, S.E. (2016) Soothing and Anti-Itch Effect of Quercetin Phytosome in 
Human Subjects: A Single-Blind Study. Clinical, Cosmetic and Investigational Dermatology, 9, 55-62. https://doi.org/10.2147/CCID.S98890

[99] Peres, D.A., de Oliveira, C.A., da Costa, M.S., Tokunaga, V.K., Mota, J.P., Rosado, C., Consiglieri, V.O., Kaneko, T.M., Velasco, M.V. and Baby, A.R. (2016) Rutin Increases Critical Wavelength of Systems Containing a Single UV Filter and with Good Skin Compatibility. Skin Research and Technology, 22, 325-333. https://doi.org/10.1111/srt.12265

[100] Choi, S.J., Lee, S.N., Kim, K., Joo, D.H., Shin, S., Lee, J., Lee, H.K., Kim, J., Kwon, S.B., Kim, M.J., Ahn, K.J., An, I.S., An, S. and Cha, H.J. (2016) Biological Effects of Rutin on Skin Aging. International Journal of Molecular Medicine, 38, 357-363. https://doi.org/10.3892/ijmm.2016.2604

[101] Yuan, X.Y., Pang, X.W., Zhang, G.Q. and Guo, J.Y. (2017) Salidroside's Protection against UVB-Mediated Oxidative Damage and Apoptosis Is Associated with the Upregulation of Nrf2 Expression. Photomedicine and Laser Surgery, 35, 49-56. https://doi.org/10.1089/pho.2016.4151

[102] Wu, D., Yuan, P., Ke, C., Xiong, H., Chen, J., Guo, J., Lu, M., Ding, Y., Fan, X., Duan, Q., Shi, F. and Zhu, F. (2016) Salidroside Suppresses Solar Ultraviolet-Induced Skin Inflammation by Targeting Cyclooxygenase-2. Oncotarget, 7, 25971-25982.

[103] Kimura, Y. and Sumiyoshi, M. (2011) Effects of Baicalein and Wogonin Isolated from Scutellaria baicalensis Roots on Skin Damage in Acute UVB-Irradiated Hairless Mice. European Journal of Pharmacology, 661, 124-132. https://doi.org/10.1016/j.ejphar.2011.04.033

[104] Chi, Y.S., Lim, H., Park, H. and Kim, H.P. (2003) Effects of Wogonin, a Plant Flavone from Scutellaria radix, on Skin Inflammation: In Vivo Regulation of Inflammation-Associated Gene Expression. Biochemical Pharmacology, 66, 1271-1278. https://doi.org/10.1016/S0006-2952(03)00463-5

[105] Fields, K., Falla, T.J., Rodan, K. and Bush, L. (2009) Bioactive Peptides: Signaling the Future. Journal of Cosmetic Dermatology, 8, 8-13. https://doi.org/10.1111/j.1473-2165.2009.00416.x

[106] Linder, J. (2012) The Science behind Peptides. Plastic Surgical Nursing, 32, 71-72. https://doi.org/10.1097/PSN.0b013e3182577344

[107] Schagen, S. (2017) Topical Peptide Treatments with Effective Anti-Aging Results. Cosmetics, 4, 16. https://doi.org/10.3390/cosmetics4020016

[108] Farwick, M., Grether-Beck, S., Marini, A., Maczkiewitz, U., Lange, J., Kohler, T., Lersch, P., Falla, T., Felsner, I., Brenden, H., Jaenicke, T., Franke, S. and Krutmann, J. (2011) Bioactive Tetrapeptide GEKG Boosts Extracellular Matrix Formation: In Vitro and in Vivo Molecular and Clinical Proof. Experimental Dermatology, 20, 602-604. https://doi.org/10.1111/j.1600-0625.2011.01307.x

[109] Marini, A., Farwick, M., Grether-Beck, S., Brenden, H., Felsner, I., Jaenicke, T., Weber, M., Schild, J., Maczkiewitz, U., Kohler, T., Bonfigli, A., Pagani, V. and Krutmann, J. (2012) Modulation of Skin Pigmentation by the Tetrapeptide PKEK: In Vitro and in Vivo Evidence for Skin Whitening Effects. Experimental Dermatology, 21, 140-146. https://doi.org/10.1111/j.1600-0625.2011.01415.x

[110] Mathur, D., Mehta, A., Firmal, P., Bedi, G., Sood, C., Gautam, A. and Raghava, G.P.S. (2018) TopicalPdb: A Database of Topically Delivered Peptides. PLoS ONE, 13, e0190134. https://doi.org/10.1371/journal.pone.0190134

[111] Pyun, H.B., Kim, M., Park, J., Sakai, Y., Numata, N., Shin, J.Y., Shin, H.J., Kim, D.U. and Hwang, J.K. (2012) Effects of Collagen Tripeptide Supplement on Photoaging 
and Epidermal Skin Barrier in UVB-Exposed Hairless Mice. Preventive Nutrition and Food Science, 17, 245-253. https://doi.org/10.3746/pnf.2012.17.4.245

[112] Aldag, C., Nogueira Teixeira, D. and Leventhal, P.S. (2016) Skin Rejuvenation Using Cosmetic Products Containing Growth Factors, Cytokines, and Matrikines: A Review of the Literature. Clinical, Cosmetic and Investigational Dermatology, 9, 411-419. https://doi.org/10.2147/CCID.S116158

[113] Fitzpatrick, R.E. and Rostan, E.F. (2003) Reversal of Photodamage with Topical Growth Factors: A Pilot Study. Journal of Cosmetic and Laser Therapy, 5, 25-34. https://doi.org/10.1080/14764170310000817

[114] Gorouhi, F. and Maibach, H.I. (2009) Role of Topical Peptides in Preventing or Treating Aged Skin. International Journal of Cosmetic Science, 31, 327-345. https://doi.org/10.1111/j.1468-2494.2009.00490.x

[115] Malerich, S. and Berson, D. (2014) Next Generation Cosmeceuticals: The Latest in Peptides, Growth Factors, Cytokines, and Stem Cells. Dermatologic Clinics, 32, 13-21. https://doi.org/10.1016/j.det.2013.09.003

[116] Bos, J.D. and Meinardi, M.M. (2000) The 500 Dalton Rule for the Skin Penetration of Chemical Compounds and Drugs. Experimental Dermatology, 9, 165-169. https://doi.org/10.1034/j.1600-0625.2000.009003165.x

[117] Benson, H.A. and Namjoshi, S. (2008) Proteins and Peptides: Strategies for Delivery to and Across the Skin. Journal of Pharmaceutical Sciences, 97, 3591-3610. https://doi.org/10.1002/jps.21277

[118] Kumar, S., Zakrewsky, M., Chen, M., Menegatti, S., Muraski, J.A. and Mitragotri, S. (2015) Peptides as Skin Penetration Enhancers: Mechanisms of Action. Journal of Controlled Release, 199, 168-178. https://doi.org/10.1016/j.jconrel.2014.12.006

[119] Priyanka, K. and Singh, S. (2014) A Review on Skin Targeted Delivery of Bioactives as Ultradeformable Vesicles: Overcoming the Penetration Problem. Current Drug Targets, 15, 184-198. https://doi.org/10.2174/1389450115666140113100338

[120] Man, M., Hupe, M., Mackenzie, D., Kim, H., Oda, Y., Crumrine, D., Lee, S.H., Martin-Ezquerra, G., Trullas, C., Mauro, T.M., Feingold, K.R., Elias, P.M. and Man, M.Q. (2011) A Topical Chinese Herbal Mixture Improves Epidermal Permeability Barrier Function in Normal Murine Skin. Experimental Dermatology, 20, 285-288. https://doi.org/10.1111/j.1600-0625.2010.01205.x

[121] Hou, M., Sun, R., Hupe, M., Kim, P.L., Park, K., Crumrine, D., Lin, T.K., Santiago, J.L., Mauro, T.M., Elias, P.M. and Man, M.Q. (2013) Topical Apigenin Improves Epidermal Permeability Barrier Homoeostasis in Normal Murine Skin by Divergent Mechanisms. Experimental Dermatology, 22, 210-215.

https://doi.org/10.1111/exd.12102

[122] Hou, M., Man, M., Man, W., Zhu, W., Hupe, M., Park, K., Crumrine, D., Elias, P.M. and Man, M.Q. (2012) Topical Hesperidin Improves Epidermal Permeability Barrier Function and Epidermal Differentiation in Normal Murine Skin. Experimental Dermatology, 21, 337-340. https://doi.org/10.1111/j.1600-0625.2012.01455.x

[123] Abraham, A.N., Sharma, T.K., Bansal, V. and Shukla, R. (2018) Phytochemicals as Dynamic Surface Ligands to Control Nanoparticle-Protein Interactions. ACS Omega, 3, 2220-2229. https://doi.org/10.1021/acsomega.7b01878

[124] Murakami, A. (2018) Non-Specific Protein Modifications May Be Novel Mechanism Underlying Bioactive Phytochemicals. Journal of Clinical Biochemistry and Nutrition, 62, 115-123.

[125] Tsuchiya, H. (2015) Membrane Interactions of Phytochemicals as Their Molecular 
Mechanism Applicable to the Discovery of Drug Leads from Plants. Molecules, 20, 18923-18966. https://doi.org/10.3390/molecules201018923

[126] Huang, W., Shen, S., Nimalaratne, C., Li, S., Majumder, K. and Wu, J. (2012) Effects of Addition of Egg Ovotransferrin-Derived Peptides on the Oxygen Radical Absorbance Capacity of Different Teas. Food Chemistry, 135, 1600-1607.

https://doi.org/10.1016/j.foodchem.2012.05.093 